\title{
Besedne družine predlogov in veznikov $v$ besedotvornem slovarju
}

\author{
Irena Stramljič Breznik
}

IZVLEČEK: Predlog in veznik sta kot podstavi za nove tvorjenke sicer zelo omejena, vendar ne v celoti zanemarljiva pri prikazu besednih družin. Za predloge je mogoče ugotoviti, da imajo to sposobnost $v$ primerjavi s prvotnimi le drugotni, iz česar je mogoče sklepati, da motivacijsko moč črpajo iz svojih izvornih prislovnih, pridevniških ali samostalniških podstav, ki so na sinhroni ravni z uveljavitvijo predložnega pomena zakrite. Vezniki so podstavno omejeni le na tvorbo novih veznikov, in to s sklapljanjem.

ABSTRACT: Prepositions and conjunctions are only rarely used as bases in word-formation processes, but they should not be completely neglected in the presentation of word families. The primary prepositions do not appear in the word-formation processes, but the secondary ones do. This indicates that their motivational ability originates their original adverbial, adjectival or nominal bases, which are no longer evident from the synchronic level, since they are substituted with the prepositional meaning. The conjunctions can only form new conjunctions - and only by means of concatenation.

0 Predlogi in vezniki so nepregibna besedna vrsta, ki nimajo predmetnega pomena, ampak le slovničnega. To pomeni, da obe besedni vrsti izražata slovnična razmerja: in sicer predlogi izražajo podredna skladenjska razmerja med besedami oz. besednimi zvezami, tj., zahtevajo njihovo določeno sklonsko obliko; vezniki pa izražajo pod- in priredno razmerje med besedami in besednimi zvezami ter tudi med stavki.

1.0 Po svoji naravi so lahko tako predlogi kot vezniki prvotni ali pa drugotni, tj., tvorbeno nastali iz drugih besednih vrst. Slednje je bilo v slovenskem besedotvorju najsistematičneje obdelano pri J. Toporišiču;' na podlagi tega je mogoče predstaviti v nadaljevanju prikazane bistvene tvorbene lastnosti obeh besednih vrst.

1.1 Predlogi najpogosteje nastajajo s konverzijo (sprevržno ${ }^{2}$ izpeljavo) in

1 J. Toporišič, Slovenski jezik in sporočanje 2, Maribor 2000, 134-135

2 J Toporišič, Enciklopedija slovenskega jezika, Ljubljana 1992, 301-302. 
sklapljanjem. Najpogostejša je konverzija iz prislova tako, da se izgubi naglasnost: (hodi) blizu > blizu (mésta); (šel je) mímo > mimo (réda); (bil je) zúnaj > zunaj (hiše); (stopi) čéz > čez (césto).

Sklopi nastajajo s sklapljanjem več predlogov: iz med $>$ izmed; iz pod $>$ izpod, iz nad > iznad; ali iz sklopljene predložne zveze: na mésto > namésto.

1.2 Tudi vezniki nastajajo s sprevrženjem, kot sklopne tvorjenke in le izjemoma kot modifikacijske tvorjenke. Za konverzne izpeljanke gre v primerih: zakáj (delaš) > (odšel je,) zakaj (ni mogel več delati); zató (ne pridem) > (padel je), zató (ga boli).

Dovolj običajni so sklopi iz veznikov in členkov: če prav > čeprav, ako ravno $>$ akoravno, medtem ko so pri tvorbi veznikov modifikacije prej izjema kot pravilo. Za modificiran poudarjalni pomen gre npr. pri paru zato : zato-rej < posebej zato.

2.0 Drugo zanimivo vprašanje, ki pa še ni bilo posebej obdelano, pa je vprašanje, v kolikšni meri sta lahko omenjeni besedni vrsti sami podstavi za nove tvorjenke in katerih besednih vrst so. Predpostaviti je mogoče, da je tovrstna tvorba sicer redka in lastna le omejenemu številu predlogov in veznikov, vendar spet ne tako obrobna, da bi jo lahko v celoti zanemarili. Še zlasti ne v primeru, če razmišljamo o besednodružinskem slovarju, ki bi vseboval podatke o tvorbeni sposobnosti sleherne netvorjenke vseh devetih besednih vrst, ki ima ob sebi vsaj eno tvorjenko.

$\mathrm{V}$ ta namen je bilo treba pregledati in preveriti obstoj potencialnih besednih družin predlogov in veznikov - četudi le $\mathrm{z}$ enim členom - po elektronski izdaji SSKJ.

\subsection{Besedna družina}

Po definiciji je besedna družina večji ali manjši sestav besed, ki jih druži skupni koren. ${ }^{3}$

Sestavine besedne družine so medsebojno odvisno povezane, to povezavo pa je mogoče določiti na podlagi poznavanja njihovih besedotvornih lastnosti, ki jih je nato treba še razvrstiti na podlagi določenih formalnih pravil. ${ }^{4}$

3.1 Razvrstitev tvorjenk ureja torej več formalnih načel, ki so v naslednjem hierarhičnem odnosu:

a) besednovrstno merilo,

b) besedotvornovrstno merilo,

3 Op. 1, 89, in op. $2,7$.

4 I. Stramljič Breznik, Prikaz besedne družine v besedotvornem slovarju, Studia Slavica Savariensia (2001), št. 1-2, 18-31.

I. Stramljič Breznik, Besedna družina besede, Jezikoslovni zapiski 6 (2000), 45-55. Tu naj samo dodam še dva popravka (kar je glede na zahteven tehnični zapis s številnimi pomiki pravzaprav malo) k napakam, ki so se pojavili pri zapisu besedne družine kljub vestnemu avtoričinemu in urednikovem pregledu: tvorjenke brez-besed-je, brez-besed$e n$ in do-besed-en so dejansko prvo- in ne drugostopenjske; tvorjenka ubesed-en je tretjestopenjska, njuni tvorjenki ubeseden-ost in ne-ubeseden pa četrto- in ne petostopenjski, kot kaže zapis. 
Zapisi v SSKJ in BSJ (zgledi iz njega so označeni z zvezdico*) so potrdili, da imajo svoje besedne družine le pravi predlog kljub, hkrati pa še proti in zoper, ki imata $\mathrm{v}$ slovenščini predložni in prislovni pomen. Tvorjenke s prek najverjetneje pripadajo le prislovnemu pomenu, npr. iti prek > prečkati 'iti na drugo stran/drugam' in iz prečka$t i$ izhajajo tvorjenke različnih stopenj: prečka, prečkanje, prečkast, preprečkati.

$K l j u b$ je po SSKJ pravi predlog, ki je s sinhronega stališča netvorjenka oz. se je občutek tvorjenosti popolnoma izgubil. Bezlaj in Snoj ga namreč razlagata kot sklop iz $k+$ ljubo in je starinski kalk $z$ Liebe ${ }^{5}$ oz. zuliebe 'na ljubo', ${ }^{6}$ vendar ima danes ravno nasprotni pomen.

Zoper je drugotni predlog, nastal iz prislova, za katerega Snoj domneva, da je po vsej verjetnosti poprislovljen samostalnik s prvotnim pomenom *'nasprotnik' ?

Tudi proti je po $\mathrm{Snoju}^{8}$ prvotno predlog in na drugem mestu tudi prislov, podobno kot pri Bezlaju. ${ }^{9}$

Prav zoper in proti kažeta, da ni vselej lahko določiti, ali je prvotni pomen predložni ali prislovni in kateri izmed njiju je motivirajoči za besedno družino, še zlasti, ker etimologija izhaja iz diahronega raziskovalnega načela - ustrezno motivacijo skuša poiskati postopno, s potrditvami iz zgodovine jezika in s primerjavami sorodnih jezikov. To pa je $\mathrm{v}$ primerjavi $\mathrm{z}$ besedotvorjem nasprotni postopek, saj besedotvorje izhaja iz sinhronega načela - kar pomeni, da za netvorjenko velja vsaka beseda, ki ji na sinhroni ravni ni mogoče določiti besede, iz katere je tvorjena. Prav razmejevanje med obema pristopoma in odločitev, v koliki meri še upoštevati etimološki vidik, predstavljata eno najtežjih dilem besedotvornih raziskovanj.

Prav iz omenjenega razloga je v nadaljevanju na prvem mestu prikazana besedna družina predloga $k l j u b$, ki v slovenščini prislovnega pomena sploh nima, nato pa jima sledita še zoper in proti, ki imata $\mathrm{v}$ iztočnici označen predložni in prislovni pomen, saj ju s sinhronega vidika ni mogoče razmejiti, čeprav velja splošno načelo, da so se predlogi navadno razvili iz prislovov. ${ }^{10}$ Slednjič pa je potrebno omeniti, da najdemo takšno kompromisno odločitev označevanja obeh besednih vrst pri podobnih primerih tudi v ruskem besedotvornem slovarju. ${ }^{11}$

kljúb predl. $\mathrm{z}$ dajalnikom

$\begin{array}{lllll}1 & 2 & 3 & 4 & 5\end{array}$

naxkljúb prisl. ${ }^{12}$

nakljúb predl.

5 F. Bezlaj, Etimološki slovar slovenskega jezika 2: K-O, Ljubljana 1982, 43.

${ }^{6}$ M. Snoj, Slovenski etimološki slovar, Ljubljana 1997, 238, in A. Bajec, Besedotvorje slovenskega jezika 4, Ljubljana 1959, 141.

7 Op. 6, 752 .

8 Op. 6, 509.

9 F. Bezlaj, Etimološki slovar slovenskega jezika 3: P-S, Ljubljana 1995, 128.

${ }^{10}$ A. Bajec, Besedotvorje slovenskega jezika 4, Ljubljana1959, 9.

" Prim. Tihonov, Slovoobrazovatel'nyj slovar' russkogo jazyka, Moskva 1985, 833.

${ }^{12}$ Znak $\times$ pomeni sklopno obrazilo. V nadaljnjem prikazu se predpostavlja, da je prvotnejši sklopljen prislov iz $n a+k l j u b$ in iz njega konverzno izpeljan predlog, enako pri navkljub in $v k l j u b$. 
Prid.

$\begin{array}{ll}\text { I(n, m, k, p) } & << \\ \text { Tpz } & >\text { in }<< \\ \text { Se } & >>\text { in }<< \\ \text { Z(m.-p) } & >>\text { in } \\ \text { Z (m.) } & >>\end{array}$

Skl

\section{Prisl.}

$\mathrm{I}(\mathrm{n}, \mathrm{m}, \mathrm{k}, \mathrm{p}) \quad<$

$\mathrm{Tpz} \quad>$ in $<<$

$\mathrm{Se}$

$>>$

$\mathrm{Z}(\mathrm{m} . \mathrm{p}) \quad>>$ in $<<$

$\mathrm{Z}(\mathrm{m}.) \quad \gg$

Skl

itd.

Kotnika v levo pomenita, da se tvorjenke razvrščajo po odzadnji abecedi, kotnika $v$ desno, da pri razvrščanju tvorjenk velja običajno abecedno zaporedje prvih sestavin. Kotniki v levo in desno pa pomenijo, da je po navajanem zaporedju treba upoštevati obe razvrstitvi.

\subsection{Besedne družine predlogov}

Po slovarskem zapisu obstaja 121 predlogov. S kvalifikatorjem predlog je zajetih več skupin: (1) kot predlogi so označeni: brez, glásom, $h$, iz, izmed, iznad, izpod, izpred, izven, izza, kljúb, kôncem, kôncu, na, nad, nalik, namésto, napram, niže, o, ob, od, po, počétkom, pod, pokàj, posréd, pótem, pótom, povódom, pred, pri, raz, s, skôncem, sréd, tékom, v, vis-à-vis, vrh, vsled, vzlíc, z, za, zadélj, zaràd, zarádi, zavolj, zavóljo, zbog, zdólž, (2) predlogi z možno enakovredno naglasnostjo oz. breznaglasnostjo: prićo/pričo, rádi/radi, spríco/spričo, vzpríčo/vzpričo in zastrán/ zastran; (3) breznaglasna varianta je predlog, naglasna prislov: blizu, čez, prek, preko, proti, spod, spred, tik, vštric; (4) predlog ali prislov, v obeh primerih je beseda naglašena: gledé, križem, króginkróg, mímo, nakljúb, naspróti, navkljúb, navprék, navŕh, navzlic, obákraj, okóli, ónikraj, ónkraj, ónokraj, ónostran, podólž, póleg, povrh, povŕhu, preblizu, skônca, skôncema, skózi, skrája, srédi, sírom, tákraj, tíkoma, tíkraj, tóstran, vkljúb, vprék, vpríčo, vŕhu, vzdólž, vzóči, začétkom, znótraj, zóper, zráven, zúnaj; (5) predlog je, navadno nenaglašena, enakopisnica še h kakemu samostalniku, pridevniku ali prislovu: kônec, krog, med, mesto, niz, okrog, rázen.

Tu nas seveda ne bo zanimala tvorba besed iz predložnih besednih zvez, kjer predlog nastopa le kot sestavina podstave, iz česar po ustaljenem in pogostem tvorbenem vzorcu nastajajo najrazličnejše tvorjenke iz predložnih zvez. To lahko ponazorimo z naslednjimi petimi besednimi vrstami tvorjenk, kot so: samostalnik (brezglav-ec), pridevnik (brez-glav-ø), prislov (po-vrh-oma), glagol (ob-glav-i-ti), medtem ko so povedkovniki tega tipa lahko le konverzni (... je zelo brez-glav-ø).

Zanimal nas bo namreč predlog kot samostojna podstava za nove tvorjenke. 
$\begin{array}{lllll}1 & 2 & 3 & 4 & 5\end{array}$

pri-kljubováti*

za-kljubováti

zóper [pər] predl. s tožilnikom ${ }^{15}$ in zóper prisl.

zopr-stvo*

(zópr-ski)

zópršč-ina*

zópr-n

zoprn-íja

zoprn-éla*

zóprn-ik

zóprniš-tvo

zóprniš-ki*

zóprnik-ov*

zóprn-ost

zóprn-ež

zóprn-ica

zóprn-kast*

nè-zóprn*

pre-zóprn*

zóprn-o-svéž*

prijétn-o-zóprn*

zoprn-ováti*

zópr-vati

zoprv-álec*

zóprv-anje

zoprv-álen*

proti predl. $\mathrm{z}$ dajalnikom in próti prisl.

naxpróti prisl.

sxpróti prisl.

naxspróti prisl.

naspróti predl.

prot-íti

prot-íven *

protívn-ik**

protivn-ica**

protívn-ost

protív-iti se ** $^{*}$

(protívlj-enje)

nè-protívljenje*

15 J. Toporišič, Slovenska slovnica, Maribor 2000, 204: pridevnik zoprn z bogato besedno družino (zoprnež, zoprnica, zoprnost, zoprnija ...) je izpeljan iz prislova zoper. 


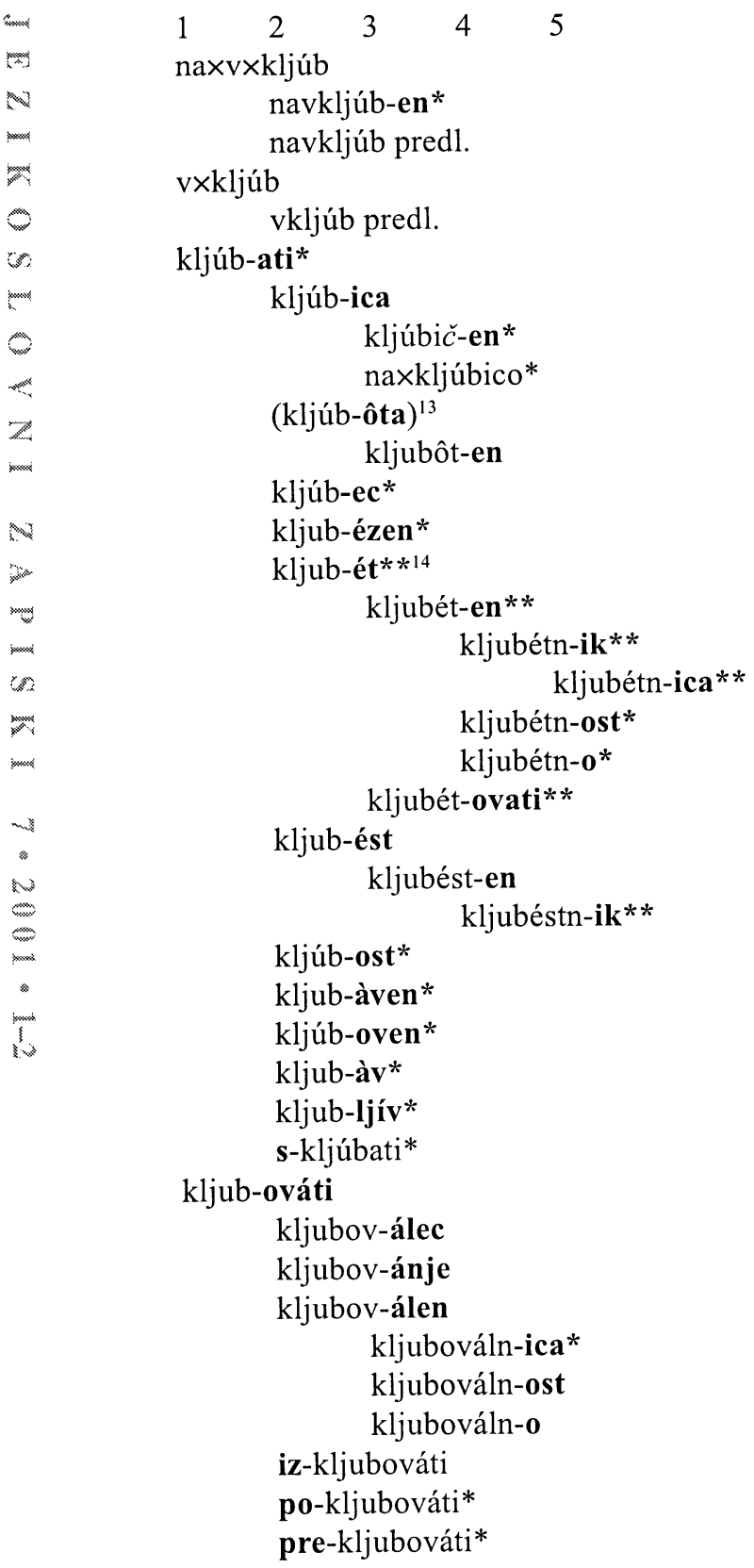

${ }_{13}$ Tvorjenka v oklepaju predstavlja manjkajoči, a predvidljivi člen besedne družine, ki ni slovarsko potrjen.

${ }^{14}$ Tvorjenka $\mathrm{z}$ dvema zvezdicama $\left({ }^{* *}\right)$ pomeni, da je beseda potrjena le $\mathrm{v}$ Pleteršnikovem slovarju in je ne vsebujeta SSKJ oz. BSJ. 
Če poskušamo odgovoriti na vprašanje, zakaj se besedne družine pojavljajo ravno pri teh predlogih, potem nam posredni odgovor daje njihova etimologija, ki predpostavlja njihov nastanek iz pridevniške predložne zveze $(k l j u b)$, iz pridevniške edninske tožilniške oblike ženskega spola (proti) oz. iz poprislovljenega samostalnika (zoper). To pa pomeni, da svojo motivacijsko moč črpajo ravno iz svojih izvornih besednovrstnih podstav, ki so v sodobnem jeziku še kako bogate (pomislimo le na obsežno izsamostalniško, izpridevniško in izprislovno tvorbo v slovenščini), vendar v sinhronem pogledu z uveljavitvijo predložnega pomena dejansko zakrite.

S pregledom tvorbenih sposobnosti predlogov in veznikov smo se tako dotaknili dveh za izdelavo slovenskega besedotvornega slovarja zelo pomembnih vprašanj, in sicer:

(1) še tako omejena tvorba nekaterih besednovrstnih podstav ne more biti tako obrobna, da bi jo lahko tak slovar zanemaril, še zlasti, ker se zdi, da se prav v takih drobcih kaže izjemna tvorbena gibkost slovenščine;

(2) omenjeni zgledi pa odpirajo nadvse važno vprašanje meje med sinhronim in diahronim pri določanju besednih družin: zamišljen besedotvorni slovar slovenskega jezika izhaja iz sinhronem pogleda na jezik, ta pa predpostavlja enako sinhrono etimološko kompetenco tako avtorja kot uporabnikov slovarja, ki bi jo bilo nujno definirati.

\section{Viri in literatura}

BAJEC, Anton, Besedotvorje slovenskega jezika, IV Predlogi in predpone, Ljubljana 1959.

BEZLAJ, France, Etimološki slovar slovenskega jezika 2: K-O, Ljubljana 1982.

- - Etimološki slovar slovenskega jezika 3: P-S, Ljubljana 1995.

PLETERŠNIK, Maks, Slovensko-nemški slovar I, II, Ljubljana 1894-1895.

Slovar slovenskega knjižnega jezika z Odzadnjim slovarjem slovenskega jezika in Besediščem slovenskega jezika z oblikoslovnimi podatki: Elektronska izdaja na plošči CD-ROM. Ljubljana 1998.

SNOJ, Marko, Slovenski etimološki slovar, Ljubjana 1997.

STRAMLJIČ BREZNIK, Irena, Elementi besedotvornega slovarja v strukturi samostalniških gesel Murkovega slovensko-nemškega slovarja, Murkov zbor$n i k$, Maribor 1998, 249-258.

--Raziskovalne perspektive slovenskega besedotvorja. Zbornik Slavističnega društva Slovenije 10: Slovensko jezikoslovje danes in jutri-Slovenski slavistični kongres, Celje 1999, 112-118.

- - Prispevki iz slovenskega besedoslovja, Maribor 1999.

- - Besedna družina besede, Jezikoslovni zapiski 6 (2000), 45-55.

- - Od poljubnega do urejenega prikaza besedne družine, Slovenščina v šoli 6(2001), št. 3, 19-22.

TOPORIŠIČ, Jože, Slovenska slovnica, Četrta, prenovljena in razširjena izdaja, Maribor 2000.

- Enciklopedija slovenskega jezika, Ljubljana 1992.

- - Slovenski jezik in sporočanje 2, Maribor 1996.

TIHONOV, A. N., Slovoobrazovatel'nyj slovar' russkogo jazyka, Moskva 1985. 


\subsection{Besedne družine veznikov}

Za predloge je mogoče ugotoviti, da zelo redko nastopajo kot podstava drugim tvorjenkam. Včasih je o tovrstni sposobnosti treba celo zelo previdno sklepati, ker imajo mnogi predlogi ob sebi istoizrazne prislove.

Še bolj omejeno tvorbeno sposobnost imajo vezniki, med katerimi imajo vsaj trije sicer skromno, a omembe vredno besedno družino. To so vezniki: priredni ampak s po eno prvo- in drugostopenjsko izpeljanko ter podredna dasi in $\check{c} e$, katerih tvorjenke so le drugi vezniki, nastali s sklaplajanjem.

àmpak in ampak vez. $\mathrm{v}$ protivnem priredju

12 ampak-ováti* ampakov-ánje

dàsi in dasi vez. $\mathrm{v}$ dopustnih odvisnih stavkih

1

dasixpràv

dasixrávno

dasixtúdi

dasixvèndar*

če vez.
1
čexpràv
čexrávno
čextúdi

\section{Sklep}

Redki predlogi in vezniki, ki veljajo za slovničnopomenski besedni vrsti, imajo besedno družino, če pa le-ta obstaja, ima le izjemoma večje število členov. To še posebej velja za veznike.

Pri predlogu je sicer možnost besedne družine pogostejša, vendar je, kot je mogoče sklepati na podlagi preverjenega gradiva, pri pravih prvotnih predlogih tipa $k, z a$, pri ... ta izključena. To pomeni, da jih imajo le napravi oz. drugotni predlogi, tj. taki, ki so najpogosteje nastali s prehodom iz prislovne v predložno besedno vrsto. Taka primera sta zlasti zoper in proti, pri katerih je težko razmejiti, ali gre za izpredložno ali izprislovno tvorbo. Da je pri njunih besednih družinah dejansko mogoče misliti tudi na izpredložno tvorbo, sklepamo po analogiji s predlogom $k l j u b$, ki je v tem pogledu nekaj posebnega, saj mu sinhrono jezikovno stanje pripisuje le še predložni pomen, ne pa tudi prislovnega. Drugo potrditev, da sta besedni družini zoper in proti lahko tudi izpredložni, imamo v njuni podobni strukturiranosti kot pri kljub, tj. na prvi stopnji le prislov in glagol, pri čemer šele slednji po ustaljenih vzorcih odpira možnost za nastajanje višjestopenjskih samostalniških in pridevniških tvorjenk. 
c) abecedna razvrstitev obrazil, in sicer:

odzadnja razvrstitev desnih obrazil,

običajna abecedna razvrstitev levih obrazil,

- običajna abecedna razvrstitev korenskih morfemov pri zloženkah in sklopih.

Merila od a) do c) pa veljajo znotraj vsake, tj. prve, druge, tretje ... stopnje tvorjenosti.

3.1.1 Besednovrstno merilo. Vsaka iztočnica katere koli besedne vrste (samostalniške, glagolske, pridevniške ...) ima naslednje ustaljeno besednovrstno zaporedje tvorjenk:

- samostalniške,

- pridevniške,

- prislovne,

- povedkovniške,

- glagolske,

- predložne,

- vezniške,

- členkovne,

- medmetne tvorjenke.

Takšna je splošna shema, ki velja v okviru vsake istostopenjske razporeditve tvorjenk. Vendar pri obdelanih besednih družinah za črko B še ni bilo iztočnice, ki bi imela potrjeno celotno besednovrstno kategorijo tvorjenk. Najpogosteje se pojavlja zaporedje $\mathrm{z}$ izpolnjenimi prvimi petimi besednimi vrstami. Pri tem velja omeniti, da povedkovnik ni posebej označen v primerih, kadar gre za konverzne (izpridevniške, izprislovne, izsamostalniške primere). Tu je označevanje te kategorije nepotrebno glede na to, da ni eksplicitno označena nobena besedna vrsta tvorjenk. Dovolj je morda omemba v splošnem teoretičnem besedotvornem delu slovarja, da je večina povedkovnikov sprevržnih in da je potencialno vsaka samostalniška, pridevniška ali prislovna tvorjenka lahko povedkovnik. Ta podatek je zlasti relevanten za skladenjski vidik, ne pa morda za besedotvornega, saj táko nastajanje povedkovnikov predstavlja manj pomemben tvorbeni postopek, t. i. konverzijsko izpeljavo, pri kateri gre za spremembo oblikoslovne kategorije.

3.1.2 V okviru vsake besedne vrste pa velja trdno zaporedje navajanja besedotvornih vrst tvorjenk, ki jih razvrščamo po abecedi od leve $(>>)$ oz. od desne $(<<)$ ali po obeh smereh. To lahko ponazorimo:

\section{IZTOČNICA -e ž}

\begin{tabular}{|c|c|c|}
\hline \multirow[t]{6}{*}{ 1. stopnja } & \multicolumn{2}{|l|}{ Sam. } \\
\hline & $\mathrm{I}(\mathrm{n}, \mathrm{m}, \mathrm{k}, \mathrm{p})$ & $<<$ \\
\hline & $\mathrm{Tpz}$ & $>>$ in $<<$ \\
\hline & $\mathrm{Se}$ & $>>$ \\
\hline & $\mathrm{Z}(\mathrm{m} .-\mathrm{p})$ & $>>$ in $<<$ \\
\hline & $\mathrm{Z}(\mathrm{m})$. & $>>$ \\
\hline
\end{tabular}


VIDOVIČ MUHA, Ada, Slovensko skladenjsko besedotvorje ob primerih zloženk, Ljubljana 1988.

-- Slovensko leksikalno pomenoslovje, Govorica slovarja, Ljubljana 2001.

\title{
Word Families of Prepositions and Conjunctions in a Word-formational Dictionary
}

\author{
Summary
}

Prepositions and conjunctions have little or no lexical meaning, and only rarely they have a word family. If the word family exists, a larger amount of units is exceptional, especially for conjunctions.

Word families exist more frequently in case of prepositions, but the analysis of the corpus material has shown that there are no word families for the primary prepositions, such as $\mathrm{k}$ 'to, towards', za 'behind, for', pri 'in, at, with', etc. This means that only the secondary prepositions, i.e. the converse prepositions from adverbs, may have word families. Examples of such converse prepositions are especially zoper and proti 'against' for which it is difficult to determine whether they are deprepositional or deadverbial. The idea of deprepositional formation of word families for the above examples can be deduced from the analogy with the preposition kljub 'in spite of'. This preposition is special because in the synchronic language it carries only the prepositional meaning, whereas the adverbial meaning was lost. A second confirmation for a possible deprepositional character of the zoper and proti word families can be found in their structure, which is similar to kljub, i.e. only an adverb and a verb on the first level, from which only the latter enables the development of higher-level nominal and adjectival formations according to standard patterns.

If we try and answer the question why do the word families exist exactly for this prepositions, then an indirect answer may be found in their etymology. Their supposed origin lies in the adjectival prepositional phrase (kljub), in the adjectival form of the accusative singular, of feminine gender (proti), or in the adverbialized noun (zoper). This means that their motivational ability is drawn directly from their word-formational bases, which are, indeed, very productive in the modern language (consider only the large amount of denominal, deadjectival and deadverbial formations in Slovenian), yet in the synchronic perspective these bases are actually hidden behind the prepositional meaning.

Two important questions for compilation of a Slovenian word-formational dictionary were tackled in this overview of formational abilities of prepositions and conjunctions, and these are:

(1) no matter how limited the word-formational ability of individual bases is, it is still not so marginal that it could be ignored in this type of dictionary-especially because it seems that exactly such details show the extraordinary word-formational flexibility of Slovenian; (2) the quoted examples open a very important question of the border between the synchronic and the diachronic perspective in determining of word families: the concept of the Slovenian word-formational dictionary is based on the synchronic view, which presupposes the same level of the synchronic etymological competence on the side of both the author and the user, and this competence urgently needs defining. 


\title{
Slovenska frazeologija $v$ dosedanjih slovarjih glede na aktualna slovaropisna načela*
}

\author{
Polona Gantar
}

IZVLEČEK: V članku je podan strnjen pregled slovarjev, ki vsebujejo slovenščino, in hkrati prinašajo opazen delež slovarsko obdelane frazeologije, ter ugotavljana uporabnost sprejetega frazeološkega gradiva in slovaropisnih načel pri izdelavi sodobnega frazeološkega slovarja slovenščine. Skladno s stopnjo jezikoslovnega (in frazeografskega) védenja so kritično vrednotena slovaropisna načela $v d v o-o z$. večjezičnih frazeoloških slovarjih, medtem ko je aktualnost sprejetega frazeološkega gradiva ocenjena v nekaterih starejših splošnih slovarjih in v Slovarju slovenskega knjižnega jezika (SSKJ).

ABSTRACT: The article brings a concise overview of dictionaries containing a notable share of lexicographically treated phraseological units with Slovenian as either one of the languages or the only language. It also discusses how the phraseological units and the lexicographic principles used could be applied in compilation of a modern Slovenian phraseological dictionary. A critical evaluation of lexicographic principles in bilingual and multilingual phraseological dictionaries has been made to correspond the level of linguistic (and phraseographic) knowledge, whereas for some older general-purpose dictionaries and the Dictionary of Standard Slovenian (SSKJ) the topicality of the phraseological material has been evaluated.

0 Pobuda za pričujočo razpravo temelji na domnevi, da se frazeologiji kot sestavnem delu slovenske leksike ni mogel izogniti noben slovaropisec, ki je v slovarsko predstavitev pritegnil slovenščino. Pri tem so načini slovarske predstavitve v marsičem specifične frazeološke leksike v posameznih slovarjih po pričakovanju različni, predvsem pa $v$ različni meri zadoščajo celovitosti slovarskega opisa. Zato je namen pričujočega prispevka - tudi zato, ker se v slovenskem prostoru že nekaj časa pripravlja zasnova frazeološkega slovarja slovenščine ${ }^{1}$ - ugotoviti, v katere

* Članek je predelano in dopolnjeno uvodno poglavje magistrske naloge Teoretični vidiki zasnove frazeološkega slovarja slovenščine, Ljubljana, Filozofska fakulteta, 2001, mentorica prof. dr. Ada Vidovič Muha.

1 Zlasti Keber (2000); Kržišnik (2001) in Gantar (2001). 
namene je mogoče uporabiti v dosedanje slovarje sprejeto slovensko frazeološko gradivo ter kateri segmenti slovarske obdelave ponujajo koristne informacije slovaropiscu danes.

0.1 Kljub samoumevnosti sprejetja frazeološke leksike v slovarski fond, je specifičnost frazeologije znotraj jezikovnega oz. leksikalnega sistema vseskozi narekovala njen posebni status, ki se je v slovarski praksi izražal v podrejeni in glede na preostalo leksiko neenakovredni predstavitvi. S tega vidika in zlasti zaradi prevladujočega tujejezičnega geselskega izhodišča je prezrtost ali majhna zastopanost frazeologije v prvih slovarskih poskusih razumljiva, obenem pa je vseskozi navzoča tudi potreba po ločeni predstavitvi frazeološkega besedišča. Tako Stabej (1977) poroča o Megiserjevi objavi nekaj slovenskih in hrvaških pregovorov že leta 1592 v delu Paroemologia Polyglottus, ${ }^{2}$ ki je v dopolnjeni izdaji izšlo tudi leta 1605. Samostojno zbirko pregovornih frazemov je mogoče najti v Gutsmannovem slovarju iz leta $1789,{ }^{3}$ nekaj pregovorov je objavil Jarnik (1814), omeniti pa je treba tudi številne druge samostojne (zlasti paremiološke) zbirke ${ }^{4}$ slovenskih frazemov. ${ }^{5} \mathrm{~V}$ nadaljnjem pregledu poleg paremioloških gradivnih zbirk, npr. slovenskih frazemov v Metelkovi slovnici (1825), ${ }^{6}$ tudi niso upoštevani slovarski deli slovenskih pravopisov. $^{7}$

Slovarji, ki prinašajo opazen delež slovenske frazeologije, so izbrani glede na formalna in vsebinska merila, in sicer glede na tipološko opredelitev frazeološki : nefrazeološki. Nefrazeološki so slovarji splošnega tipa ter narečni. ${ }^{8}$ Izbor je nadalje določen glede na obseg sprejetega frazeološkega gradiva, ${ }^{9}$ znotraj tega pa še

2 O tem prim. Radics (1882: 332-334) in Levstik (1882: 640; 562-564).

3 Velik del frazeološkega gradiva iz Gutsmannovega slovarja in slovnice je zbral Grafenauer (1935).

${ }^{4}$ Suhadolnik (1960/61: 200) poroča o Jnežičevi napovedi Jožefa Vuka Polyglott Parëmiophraseologie v Slovenskem glasniku 1865 kot o »bogati zbirki prislovic in rekov v nemškem, laškem, slovenskem, francoskem, angleškem, latinskem in grškem jezi$\mathrm{ku} \ll$.

5 Seznam samostojnih ali v posameznih revijah objavljenih zbirk pregovorov in rekov (43 bibliografskih enot od leta 1844 do 1972) je mogoče najti v Bojc $\left(1980^{2}: 17-21\right)$, sicer pa vse do danes v COBISS-u. Obsežen seznam (po COBISS-u) je v Keber (2000: 97-113).

${ }^{6}$ Otem prim. Matešić, Petermann (1991).

7 Kržišnik (1996: 135) opozarja na normativno vlogo, ki so jo glede knjižnojezikovne pravilnosti (manj ustaljenosti) imeli slovarski deli pravopisov. Ker so »le-ti s frazeologijo do SP 50 zelo skopi, [lahko] o normativni vlogi slovenskega pravopisa v frazeologiji govorimo šele ob SP 50 in $62 \ll$.

8 Frazeologija v narečnih slovarjih, zlasti pri ugotavljanju narečnih variant pa tudi pomenskih odtenkov geografsko širše prepoznavnih frazemov, bi zahtevala samostojno raziskavo. Izdelano zasnovo obsežnega frazeološkega gradiva (1218 frazeoloških enot) prinaša poskusni zvezek Slovarja govorov Zadrečke doline (Weiss: 1998; zlasti Uvod: 16/ 17); s frazeološkega vidika pa bi bila zanimiva vsaj še narečna slovarja L. Karničarja (1990) in F. Novaka, zlasti druga popravljena in dopolnjena izdaja (1996).

9 Zanašam se na lastno oceno pregledanih slovarjev in na nekatere splošne ocene, prim. zlasti Breznik (1926; 1938) Humar (1998), Suhadolnik (1960/61; 1984), Kržišnik (1999). 
glede na enojezične ter dvo- in večjezične. Zadnji so obravnavani še glede na slovensko oz. tujejezično geselsko izhodišče. Rokopisni slovarji niso upoštevani. ${ }^{10}$

Izbor slovarjev slovenskega jezika, ki vsebujejo frazeološko gradivo, glede na formalna in vsebinska merila

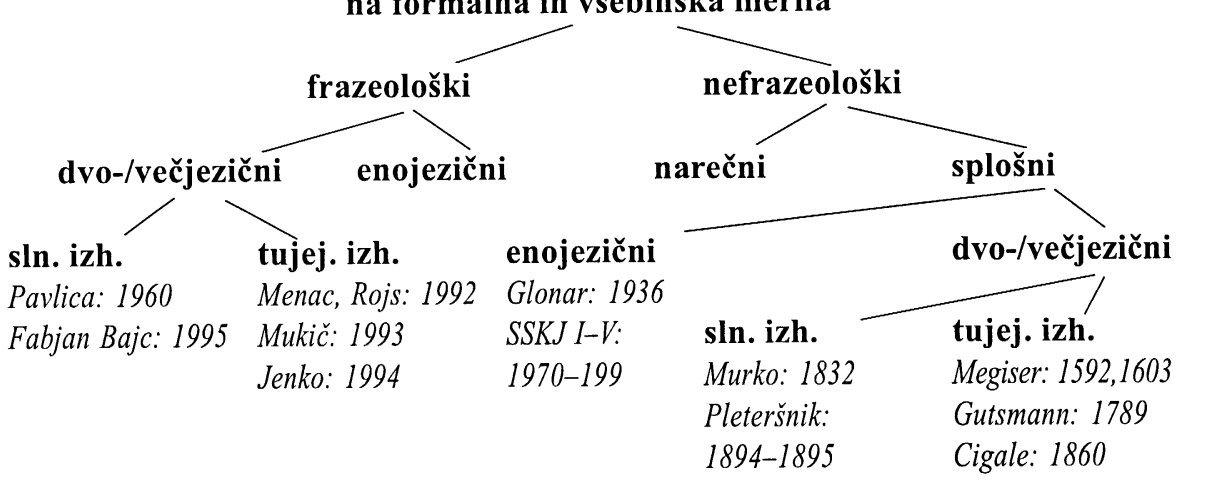

\section{Frazeološko gradivo v splošnih eno- in večjezičnih slovarjih slovenskega jezika}

1.0 V času oblikovanja slovenskega knjižnega jezika, tj. v času zavestnega vzpostavljanja njegovih temeljnih razpoznavnih lastnosti, je bila poglavitna vloga slovarja skupaj s slovnico njegova normativna ustalitev (Vidovič Muha 1996: 19), do neke mere pa tudi izraz narodnopredstavitvene vloge jezika, zlasti v smislu sopostavitve slovenščine ob bok ne samo številčno močnejšim, vplivnejšim (latinščina), pač pa tudi polnofunkcionalnim državnim jezikom, kot sta bila nemščina in italijanščina. Pomembno vlogo v tem smislu imata Megiserjeva slovarja s konca 16. in začetka 17. stoletja, pa tudi domnevno Kastelčev Slovensko-latinski slovar, kot prvi slovar s slovenskim geselskim izhodiščem (Stabej: 1997: 564). Čeprav delež frazeologije v prvih slovarskih delih ni neopazen, je zaradi poudarjanja »enakosti« jezikovnih zmožnosti slovenščine nasproti drugim evropskim jezikom, manj pa posebnosti, drugačnosti, v primerjavi s kasnejšimi slovarji ${ }^{11}$ manj pomemben.

1.1 Posebno mesto med dvojezičnimi slovarji - tudi z vidika obsega frazeološkega gradiva - ima Gutsmannov Nemško-slovenski slovar (1789). Ob njem je bilo izraženo spoznanje, da je na zgodovino razvoja in oblikovanja besedišča neke jezikovne skupnosti potrebno gledati kot na neposredni odraz njenega duhovnega

${ }^{10} \mathrm{Za}$ celovit pregled zgodovinske frazeologije bi bila zanimiva zlasti Vodnikov (18061817) in Hipolitov (1711-1712) rokopisni slovar, prim. Stabej (1966: 44; 1997: 565).

"Zlasti obdobje romantike, ki ga v slovarskem smislu zaokrožata Gutsmannov (1789) in Murkov slovar $(1832 ; 1833)$, pomembno pa se kaže tudi v Pleteršnikovem slovarju (1894/ 95), je obdobje, ki je »vjezikoslovju na široko odprlo vrata zbiranju frazeoloških enot (resda predvsem pregovornega tipa, a ne samo) in njihovemu uvrščanju v slovarje in zbirke« (Kržišnik 1999: 317). 
osvajanja sveta (Prunč 1979: 210). Tako je tudi za vrednotenje frazeološkega gradiva v posameznem slovarju nujno upoštevati dejstvo, da je bil slovarski dosežek vedno rezultat leksikografove osebne recepcijske sposobnosti, pri izboru gesel pa tudi njegove domneve o poimenovalnih in izraznih potrebah naslovnika.

$1.2 \mathrm{Z}$ vidika sprejetega frazeološkega gradiva je $\mathrm{v}$ smislu naslonitve na pristno in živo slovenščino (Stabej 1966: 42) pomembna Vodnikova slovarska zamisel na začetku 19. stol., ki je izhajala iz aktualnih evropskih zgledov tistega časa. Nastalo je obsežno gradivo takratne žive slovenščine, uresničeno v rokopisnem slovarju, ki pa je bilo kasneje izročeno Pleteršniku, v veliki meri pa ga je uporabljal že Cigale. ${ }^{12}$ Slovar je pomemben tudi zaradi tega, ker prvič navaja slovenske ustreznike nemškim pregovorom (Stabej 1966: 44), npr. du hast mir Ursache dazu gegeben - ti si me k timu napelal; der Jungend Fleis ist der Alter Ehre - mladost stari ćastito starost; mit der heissen Nadeln nähen - tje v en dan delati; Hopfen und Malz verlieren - prazno slamo mlatim ali bob v steno metam; hab ich ist besser als hät ichbolj je derži ga ko lovi ga itd.

1.3 Popoln izpis frazeologije iz Murkovega slovarja (1832) je mogoče najti v Kržišnik (1999: 318-345), pri čemer je zavrnjena Breznikova ugotovitev o tesni navezavi na Gutsmannov slovar. Avtorica ugotavlja, da je v Murkovem slovarju glede na Gutsmanna dvakrat toliko frazeoloških enot. Zlasti bogat je slovar $\mathrm{z}$ variantami, ki jih pri Gutsmannu ni mogoče najti. Različnost virov frazeološkega gradiva potrjuje tudi ugotovitev nekaterih variant pri Gutsmannu, ki jih Murko ne izkazuje. V smislu upoštevanega gradiva je za preverjanje variant - tudi $z$ današnjega vidika - pomembna sicer že Breznikova (1938: 22) ugotovitev, da je zbral »vse, kar se nahaja $\mathrm{v}$ literaturi«.

1.4 Pomembnost Cigaletovega Nemško-slovenskega slovarja (1860), Glonarjevega Slovarja slovenskega jezika (1936) in Pleteršnikovega Slovensko-nemškega slovarja (1894) se kaže v možnosti preučevanja pomenskega, sestavinskega, variantnega ipd. razmerja $\mathrm{z}$ nemškimi frazemi, $\mathrm{v}$ Cigaletovem slovarju pa so pogosto izkazane tudi vzporednice in izposojenke iz drugih slovanskih jezikov (Keber 2000: 84), še pomembnejši se zdijo pomenski premiki, ki so jih nekateri frazemi pridobili s časovnim odmikom. Za ponazoritev navajam nekaj primerjav med slovenskimi frazemi in nemškimi (1) frazemskimi ustrezniki ali (2) nefrazemskimi opisi v Pleteršnikovem Slovensko-nemškem slovarju:

(1) Kačo v žepu imeti - Kein Geld im Sack haben ${ }^{13}$ kesne glave biti-ungelehrig, ein langsamer Kopf sein; noga mi melje; noga v mlin gre - der Fuß ist mir eingeschlafen; na mojo mošnjo - auf meine Rechnung; kačja zalega - (fig.) das Rattergezücht

(2) izpod kape gledati - einen unaufrichtigen Blick haben

Uvrstitev frazeološke leksike pod posamezne pomene in zlasti v ponazarjal-

${ }^{12}$ Stabej (1966: 43) navaja, da je Cigale v svoj slovar (1860) prevzel več kot 95 odstotkov Vodnikovega gradiva, posebej omenja tudi velik del od Vodnika sprejetega nemškega frazeološkega gradiva.

${ }^{13}$ Razlaga karg sein ('biti skop; skopariti') kaže na pomenski premik. Po SSKJ frazem imeti kačo $v$ žepu - pomeni 'biti brez denarja'. 
no gradivo ${ }^{14}$ je odraz Pleteršnikove zavesti o pomembnosti in posebnosti frazeologije znotraj celovitega izraznega potenciala narodovega jezika. Frazeološko besedišče je namreč pri izražanju razmerja do upovedenega glede na druga ekspresivna jezikovna sredstva posebno v tem, da glede na nastanek izraža subjektivno razmerje, ki pa je hkrati rezultat kolektivnega (narodovega) doživljanja pojavnosti (Kržišnik Kolšek 1991: 90). Z bogatim frazeološkim gradivom, ki ga je sprejel v slovar, je Pleteršnik potrdil večkrat izpostavljeno misel, da so frazemi, zlasti znotraj paremiologije, tista ekspresivna jezikovna sredstva, ki bolj kot katerakoli druga odražajo duha jezika in naroda, ki ta jezik govori. Pleteršnikov slovar je tako tudi prvo leksikografsko delo, ki je evidenten prikaz frazeološke rabe tistega časa s posebnim ozirom na normativne težnje, ki so se ob njem oblikovale.

1.5 Vlogo najobsežnejše in najrelevantnejše zbirke frazeološkega gradiva, ki je bila do sedaj pripisovana frazeološkemu gradivu v SSKJ,${ }^{15}$ danes prevzemajo elektronski besedilni korpusi. ${ }^{16} \mathrm{Z}$ vidika nadaljnje uporabnosti frazeološkega gradiva v SSKJ so pomembne naslednje ugotovitve:

- SSKJ z vidika splošne leksike ${ }^{17}$ relativno objektivno zajema aktualno poimenovalno gradivo slovenščine $\mathrm{v}$ dveh tretjinah 20. stol. do druge polovice 80. let (Vidovič Muha 1999: 9), kar pomeni, da je glede na korenite družbeno-politične spremembe v 90. letih, nagel razvoj medijev (radio, TV, internet) in vezanost frazeoloških izpisov pretežno na leposlovje (glej v nadaljevanju) $\mathrm{z}$ vidika današnjega uporabnika v določeni meri zastarelo, predvsem pa pomanjkljivo;

- frazeološko gradivo v SSKJ je do neke mere že slovarsko obdelano; opravljene so analize sprejetega frazeološkega gradiva (Kržišnik Kolšek 1988: 28-42) tudi z aktualizacijo frazeografskih spoznanj (Petermann 1988; Gantar 2001: 127-142).

1.5.1 Za ugotovitev dejanske uporabnosti za sodobni frazeološki slovar je ob tem nujno upoštevati še (a) načela zbiranja in izpisovanja virov, določenih za izpis gradiva, ter načela, ki so določala zajetje izpisanega gradiva v slovar in (b) pojem knjižnojezikovne informativne normativnosti.

1.5.1.1 Zbiranje gradiva je bilo v najzgodnejši zasnovi SSKJ podrejeno zamisli o predstavitvi celotnega slovenskega besednega zaklada, $v$ nadaljevanju pa se

${ }^{14}$ Humar (1998: 89) opozarja na značilno vlogo ponazarjalnega gradiva v slovarjih 19. stol., namreč pokazati predvsem tisto, kar je v jeziku posebno, zanimivo.

${ }^{15}$ Zlasti Kržišnik Kolšek (1988: 23); Kržišnik 1996: 137), Petermann (1988: 307), Vidovič Muha (1999: 10), Keber (2000: 84).

${ }^{16} \mathrm{~V}$ slovenskem prostoru sta izpostavljena predvsem dva: FIDA, tj. splošni referenčni korpus kot uravnotežena reprezentativna elektronske besedilna zbirka, ter Nova BESEDA elektronska zbirka slovenskih, zlasti starejših leposlovnih in publicističnih besedil.

${ }^{17}$ Oblikovanje gradivne baze za splošne slovarje se od gradivne baze, namenjene izdelavi frazeološkega slovarja, ne razlikuje samo v izboru virov, pač pa predvsem v številu informacij, ki jih "frazeološki" izpis zahteva. Zaradi opazne (so)besedilne, pogosto tudi zunajezikovne (situacijske) navezave, ustrezne zapolnitve vezljivostnih mest, ugotavljanja skladenjske vloge, leksikalizacije paradigmatskega vzorca, vrste ekspresije ipd. je potrebno izpisati širše besedilno okolje frazema in natančno določiti vzorec izpisa, ki mora predvideti podatke o pretvorbenih možnosti frazema, kategorialnih lastnostih delovalnikov, tipični besedilni realizaciji ipd. 
je podrejalo spreminjajočim se slovarskim načrtom, kot so se oblikovali glede na nacionalne in znanstvene interese. Skladno z načrtom obnovitve Pleteršnikovega Slovensko-nemškega slovarja se je izpisovala izvirna in prevodna literatura ter publicistika prve polovice 20. stol., za izdajo velikega akademskega slovarja pa gradivo iz vseh tiskanih in rokopisnih del ter živega govora ${ }^{18}$ (Hanjšek-Holz 1997: 106). $\mathrm{Na}$ podlagi zbranega gradiva je bil leta 1951 napravljen poskus redakcije nekaj gesel, ki je med drugim pokazal, da gradivo presega Pleteršnikov slovar v frazeologiji sodobnega knjižnega jezika. Ob ustanovitvi leksikološke sekcije leta 1954 je bilo zbiranje gradiva na novo organizirano: izpisovalo se je pomembnejše sodobno leposlovje od 16. stol. dalje in bilo organizirano paberkovalno izpisovanje slovenskih slovarjev 19. stol. Izpolnila se je metoda izpisovanja: besede so se izpisovale v daljših zvezah, vpeljani so bili popolni izpisi posameznih del. Oblikovanje temeljnih izhodišč zasnove SSKJ v začetku 60. let, ki so izhajala iz spoznanj evropskega jezikovnozvrstnega funkcionalizma, so $\mathrm{v}$ smislu izbora gradiva zahtevala uravnoteženo zajetje vseh funkcijskih zvrsti, vezanih na pisni prenosnik. Za frazeologijo, ki je pretežno vezana na nestrokovna besedila in neformalne govorne položaje, prvenstveno na govorni prenosnik, torej manj relevantna. Besedilno gledano gre $\mathrm{v}$ SSKJ pretežno za frazeologijo, kot jo izkazuje leposlovje in publicistika, deloma praktičnosporazumevalna besedila prve polovice 20. stol. Pomemben je podatek, da so se ob ustaljeni zasnovi pospešeno izpisovali zlasti slovenski klasiki 19. stol.; metoda gostih izpisov je zajela v prvi vrsti frazeologijo (SSKJ 1970: XII: § 12). Med načeli, ki so določala izbor gradiva v slovar, je izpostavljena pogostnost, in sicer najmanj štirje zapisi različnih avtorjev, zapis v SP 62, v Pleteršnikovem slovarju in drugih virih; pri manj pogostih besedah pa védenje redaktorjev in zapisi pomembnih avtorjev (Hajnšek-Holz 1997: 107, op. 16).

1.5.1.2 Glede na težnje slovarja, ki so se zapisale v oznako knjižnojezikovno normativno informativni, je pojem knjižnosti mogoče razumeti v zajetju leksike vseh funkcijskih zvrsti, vezanih na pisni prenosnik, normirane s stališča knjižnega jezika (Vidovič Muha 1999: 10). Pregled s kvalifikatorjem knjižno označenih frazemov (Kržišnik 1998: 58/59) je v smislu funkcijskozvrstne vezanosti pokazal njihovo prepoznavnost glede na nastanek (metatonije in metafore iz leposlovja, frazemi, ki vsebujejo ozkoknjižno sestavino, frazemi iz grške in rimske književne in mitološke tradicije, biblijski frazemi in frazemi iz drugih, zlasti evropskih literatur), redkeje je oznaka uporabljena socialnozvrstno, torej glede na rabo. ${ }^{19}$ Opozoriti je treba tudi na nedoslednost SSKJjevega vrednotenja, ker ne ločuje stilne zaznamovanosti, vezane na jezikovno enoto, od zaznamovanosti, ki je dana z realizacijo frazema v določeni zvrsti besedila ${ }^{20}$ (prim. tudi

${ }^{18}$ Pritegnitev govornega vira je $z$ vidika relevantnosti frazeološkega gradiva pomembna informacija, žal pa nisem zasledila podatkov o načinu tovrstnega zbiranja gradiva, niti nisem opazila, da bi bilo v listkovnem gradivu za SSKJ, ki ga hrani Inštitut za slovenski jezik F. R., v zvezi s frazeologijo kdaj na govorni vir posebej opozorjeno.

${ }^{19}$ Kržišnik (1998: 59) opozarja, da na socialnozvrstno vlogo oznake knjiž. navaja tudi dejstvo, da so zgoraj omenjene skupine frazemov lahko tudi brez te oznake v skladu z drugačno rabo.

${ }^{20}$ Prim. publ. za sedeti na sodu smodnika pod izt. sedeti in samo ekspr. pod iztočnicama smodnik in sod. 
Kržišnik 1998: 63). V zvezi s tem je upravičen očitek splošni rabi oznake ekspresivno za vse frazeme namesto podatka o vrsti ekspresije.

Glede uporabnosti frazeološkega gradiva za sodobni frazeološki slovar slovenščine je torej mogoče povzeti, da je SSKJ lahko dopolnilni vir informacij tako v smislu obsega gradiva kot posameznih slovarskih podatkov, zadnje zlasti v smislu upoštevanja slovničnih in pomenskih kvalifikatorskih pojasnil (Gantar 2001: 134142), manj pa v smislu nastavitve ustreznih slovarskih oblik, določitve skladenjske vloge in pretvorbenih možnosti. Nujno potrebna je korektura in prevrednotenje pomenskih razlag, tako glede aktualnih pomenskih premikov kot tudi dopolnitev s pojasnili sobesedila in leksikaliziranih zunajjezikovnih okoliščin rabe. Povsem na novo bi bilo potrebno določiti stilno- in funkcijskozvrstno opredelitev frazemov, tj. skladno $\mathrm{z}$ rabo današnjega govorca.

\section{Frazeološko gradivo $\mathrm{v}$ dvo-/večjezičnih frazeoloških slovarjih s slovenskim geselskim izhodiščem}

2.1 O Pavličevem petjezičnem frazeološkem slovarju (1960) je bilo v slovenski literaturi že kar nekaj povedanega. ${ }^{21} \mathrm{Za}$ temeljne prvine zasnove njegovega slovarja in s tem tudi za nadaljnjo slovarsko uporabnost se zdi pomembno dejstvo, da je izbor frazeološkega gradiva narekovala izpostavitev mednarodne razsežnosti slovarja. Izbor iztočnic je namreč določalo merilo enakosti t. i. vodilne besede v vseh upoštevanih jezikih, kar naj bi omogočilo prevajanje v obeh smereh, s tem pa je avtor izbor slovenskih frazemov podredil tujemu pojmovnemu svetu. Nerodnost pri izboru gesel, ki bodisi niso izpričana v tedanji literaturi, bodisi so že zastarela, je Pavlici očital že Suhadolnik (1960/61: 202), kar je vsekakor pomemben podatek pri presojanju frazeološkega gradiva $z$ današnjega vidika.

Posebno pozornost zahteva Pavličevo pojmovanje frazeološke enote in izrazje, ki ga uporablja. Za nadaljnjo uporabnost je pomembno vedeti, da je frazeologija upoštevana v širšem smislu, saj slovar vključuje poleg pravih fraz, ki so mu pregovori, stalna rekla in rečenice, še t. i. jezikovne klišeje ter konverzacijske in korespondenčne besedne obrazce ter prispodobe. Med temi natančneje pojasnjuje le jezikovne klišeje, ki bi jih z vidike današnje terminologije lahko opredelili kot neglagolske frazeme, med katerimi izpostavlja predložne in prislovne zveze (na vrat na nos; zlepa ali zgrda) ter samostalniške besedne zveze (besedne figure). Skupni imenovalec, ki jih uvršča med fraze, je poleg formalne večbesedne zgradbe še stalnost, dobesedna neprevedljivost, deloma tudi skladenjska včlenitev.

Opis frazemskega pomena - v oklepajih za slovensko iztočnico ${ }^{22}-$ je po grobem pregledu vezan na slabo tretjino iztočnic, pri čemer ni mogoče ugotoviti ključa, po katerem je avtor razlage, navadno vezane samo na pomensko spremenjeno sestavino, pripisal nekaterim frazemom, npr. Leži v agoniji (bori se smrtjo); Dokazal je svoj

${ }^{21}$ Prim. zlasti Suhadolnik (1960/61), Kržišnik (1988: 22/23), Petermann (1988: 302).

${ }^{22}$ Vendar so v oklepajih tudi variante, npr. Poslal ga je po april (po ptičje mleko, po žabje dlake). 

alibi (da ni bil na kraju dejanja ob določenem času); Ima kolesce premalo (v njegovi glavi ni vse v redu); Ni hotel biti molzna krava (predmet izkoriščanja). Razlage so pogosto frazemski sinonimi, npr. Trdega srca je (ima srce kot kamen); To niti ne koristi niti ne škodi (To je »Blažev žegen«). V primerjavi s SSKJ je zanimivo, da Pavlica ponekod izkazuje večpomenskost ali drugačen pomen, npr. Pavlica: Barvo je spremenil (prebledel je, spremenil je svoje prepričanje); SSKJ: od jeze spreminja barve 'bledi in rdi hkrati'; Pavlica: Zgrabil je bika za rogove (lotil se je stvari od najtežje strani); SSKJ: zgrabiti bika za roge 'odločno se lotiti težkega, zahtevnega dela'.

Ugotovitev stalnega jedra frazema in določitev slovarske oblike ostajata najtežji nalogi frazeografije še danes, zato je na neki način razumljiva, s praktičnostjo in uporabnostjo utemeljena odločitev avtorja, da postavi »glagol v določno obliko, ki jo vsakdo, ki razpolaga s primernim slovničnim znanjem, lahko prikroji za dani primer «. Da taka odločitev vendarle ni vedno v prid uporabniku, kaže dejstvo, da se $\mathrm{s}$ tem zabrisujejo meje frazema in njegovega potencialnega besedilnega okolja, npr. Afera je dvignila mnogo prahu pod afera, ki ni stalna (leksikalizirana) sestavina frazema. Tako še: Beži (dirja) na vse pretege, na vrat na nos pod bežati. Uporabnejši je slovar pri frazemih, kjer je realizacijska oblika v celoti prekrivna s slovarsko, npr. To drži kot amen v očenašu! Na dan z besedo! Niti besedice več! Hvala bogu! ipd.

$\mathrm{V}$ zvezi z variantami bi bil za današnjo rabo koristen podatek o virih, saj posamezne iztočnice izkazujejo veliko število variant, obenem pa odpirajo vprašanje razmejitve variant in variantnih oblik od sopomenskih frazemov. Nekaj primerov: On je med batom in nakovalom (v kleščah); Na boben (na kant) je prišel; $N i$ črhnil, zinil, žugnil niti besede; Tega se boji ko ognja, ko kuge, ko smrti, ko hudič križa; Bil je bled ko mrlič, ko smrt, ko zid, ko prt, kot bi iz groba vstal; Dolg čas mu je; Dolg čas prodaja; od dolgega časa ga bo konec; Ima židan čas; Ima časa na pretek; Zmeraj tiči, buda v knjige; knjižni molj je.

Mogoče je reči, da je Pavličev slovar koristen vir variant in možnosti za potencialne pomenske diferenciacije, seveda ob pritegnitvi sodbe rojenih govorcev in nujni kritični presoji, ki mora upoštevati dejstvo, da je zaradi številnih individualnih posegov avtorja sprejeto frazeološko gradivo v marsičem oporečno.

2.2 Verjetno ni naključje, da je avtorica 35 let mlajšega slovensko-italijanskega frazeološkega slovarja (1995) s slovenskim geselskim izhodiščem zamejska Slovenka, saj se zdi, da so ji kot prevajalki zunaj matične domovine še toliko bolj blizu problemi, ki izhajajo še vedno tudi iz nesamoumevnosti rabe slovenščine $\mathrm{v}$ vseh govornih položajih. Frazeološke enote so, kot se zaveda, zaradi svoje zgradbe in pomenskih lastnosti še toliko bolj prikladne za tuje, v konkretnem primeru italijanske jezikovne vdore.

Za nadaljnjo uporabnost bistvena prvina zasnove - postavitev slovenščine $v$ izhodišče - tudi $v$ tem slovarju ne dosega svojega namena: sprejem frazema je poleg pogostnosti narekoval obstoj italijanskega ustreznika, čeprav avtorica ugotavlja, da so na ta način iz slovarja izločeni frazemi, specifični za slovenski pojmovni svet, hkrati pa se tudi pri prevedljivih frazemih zaveda strukturnih, stilnih, zvrstnih, pragmatičnih in nenazadnje pogostnostnih odstopanj italijanskih ustreznikov. Ob odsotnosti pomenskih razlag je torej razumevanje in raba slovenskega frazema povsem podrejena italijanskemu (bolj ali manj ustreznemu) frazemskemu ustrezniku. 
Poglavitni gradivni vir je SSKJ, dopolnilni pa avtoričini izpisi in prevodi italijanskih predlog. Pojmovanje frazeološke enote se navezuje na teorijo, ki jo v slovenskem jezikoslovnem prostoru zagovarja Toporišič (1973/74: 273-279). Skladna s tem je tudi pritegnitev strokovnih besednih zvez, sicer pa so v slovar sprejeti tudi pregovorni frazemi in izreki. Zlasti izbor strokovnih poimenovanj, npr. besedna analiza; varovalna barva; dimna bomba; prednostna cesta; prosta carinska cona; porod s kleščami ipd. bi od dejstvu, da pomeni niso navedeni, zahteval terminološko oznako, sicer je pogosto nemogoče ugotoviti, ali gre za zvezo s konkretnim denotatom, npr, pri iti v bunker, ali za ekspresivni idiomatični izraz tipa iti rakom žvižgat ali zgolj za stalno besedno zvezo (kolokacijo), kar predvidevam da je zveza vživeti se v novo okolico. Stanje dodatno zapleta dejstvo, da stojita znotraj enega gesla primera kot poslovilna in zadnja večerja, nikjer pa ni nakazano, da gre $\mathrm{v}$ prvem primeru za sestavo ('večerja ob slovesu'), v drugem pa za religiozni izraz, ki označuje biblijski dogodek (v SSKJ v terminološkem gnezdu).

Navajanje frazemov v slovarski obliki načeloma ustreza slovarski praksi, odstopanja so predvsem v sledečem.

(a) Nepopolna slovarska oblika, zlasti pri povedkovniških frazemih, npr. naš človek (SSKJ: to je naš človek 'privrženec somišljenik', ne pa tudi 'pripadnik istega naroda glede na govorečega'); bela vrana (SSKJ: ekspr. tak delavec je v podjetju bela vrana 'redkost').

(b) Neustrezna slovarska oblika, npr. kislo nategovati obraz (SSKJ: kaj bi delal kisel obraz 'kazal nejevoljo'). Zavajajoče so tudi slovarske oblike z glagolsko sestavino v nedoločniku, ko gre bodisi za samostojni pomen besede, npr. biti babilonščina, ${ }^{23}$ ali ko gre za frazem s strukturo stavka in besedilno zapolnljivim desnim določilom, npr. boleti glava zaradi česa (glava boli koga zaradi koga/česa); kri zastati $v$ žilah (kri zastane $v$ žilah komu).

(c) Navajanje (običajnega) besedilnega okolja v slovarski obliki, npr. uiti komu vlak pred nosom (SSKJ: avtobus ji je odpeljal izpred nosa, pred nosom 'ko je bila že zelo blizu'; trgovino ima pred nosom 'zelo blizu'; zavojček mu je pred nosom pofulil ['v njegovi neposredni navzočnosti']; vrata mu je pred nosom zaprla 'očitno je pokazala, da ga ne želi sprejeti'). ${ }^{24}$

(č) Nedosledno navajanje vezljivostnih mest v slovarski obliki, npr. pasti mrena z oči (mrena pade z oči komu); dati popra/vetra (dati popra/vetra komu); nobene ne ostati dolžan (nobene ne ostati dolžan komu).

(d) Neustrezna sestavina ali oblika sestavine frazema, npr. Roka roko umiva (SSKJ: roka roko umije); Sad ne pade daleč od drevesa (SSKJ: Jabolko ne pade daleč od drevesa; Bojc (19822: 309) Jabolko ne pade daleč od debla (-od drevesa, - jablane), le potoči se (včasih); Kocbek, Šašelj (1934: 62) Jabolko ne pade daleč od debla, le potoči se. Jabolko ne pade daleč od drevesa.).

${ }^{23}$ Neustrezna je tudi zapolnitev levega delovalnika $\mathrm{z}$ lastnostjo živo+, na kar napeljuje nedoločnik.

${ }^{24}$ Po SSKJ je mogoče sklepati na na tri samostojne frazeme oz. njihove variante, in sicer na (a) prislovni frazem z različno sklonsko realizacijo: izpred nosa; pred nosom ter (b) na glagolska frazema: imeti kaj pred nosom in zapreti komu vrata pred nosom. 
Razvrstitev frazemov sledi določitvi gesla, ki je »najvažnejša ali najbolj ekspresivna beseda.« Posamezna gesla in pripadajoči frazemi so nato razvrščeni v 16 tematskih poglavij. Vendar pa se taka razvrstitev ne zdi najbolj posrečena, zlasti v primerih, ko je težko določiti najbolj ekspresivno besedo in jo uvrstiti v ustrezno tematsko poglavje. Če npr. za metati $k$-u polena pod noge določimo polena kot najbolj ekspresivno besedo, bomo težko našli poglavje, v katerem se nahaja, namreč Rastline. Težava je tudi, kadar je kak plod, rastlino mogoče pojesti, pa potem ne vemo, ali iskati frazem biti poln kot lešnik pod Rastline (kjer ga ni) ali pod Hrana in pijača, kjer najdemo tudi primere kot biti kot konjska figa, za vsako / najmanjšo/ prazno figo, kar seveda odpira problem enakoizraznosti. Avtorica se je očitno zavedala, da je na ta način skoraj nemogoče poiskati frazem v enem samem poizkusu, zato je na koncu dodala abecedni seznam vseh gesel in frazemov, ki jim pripadajo. Slabo pri tem je, da so prislovne geselne besede navedene pod pridevniki, npr. bajno zaslužiti pod bajen; debelo gledati pod debel; biti dobro zapisan pri $k-m$ pod dober, medtem ko se zdi, vsaj z uporabniškega vidika, sprejemljivejše uvrščanje posamostaljenih pridevniških sestavin pod pridevnike, npr. ne črhniti ne bele ne črne pod bel; spraviti na hladno pod hladen; trě̌čiti z jasnega pod jasen.

\section{Frazeološko gradivo v dvo-/večjezičnih frazeoloških slovarjih s tujim geselskim izhodiščem}

3.1 Podrobno oceno Hrvatsko-slovenskega frazeološkega slovarja (1992), zlasti glede na upoštevanje načela enakovrednosti in v uvodu izpostavljenega razmerja aktivno - pasivno, je mogoče najti v Kržišnik (1995/96), zato se mu tu ne bom posebej posvečala, pač pa bom nekoliko podrobneje ovrednotila frazeološko gradivo v obeh preostalih »zamejskih« frazeoloških slovarjih.

3.2 Glede na čas izida prvi je Francka Mukiča Madžarsko-slovenski frazeološki slovar (1993), ki hkrati ponuja najmanj za nadaljnjo slovarsko delo uporabnega gradiva, ki ob vsem tudi ni slovarsko obdelano.

Bistvena prvina slovarske zasnove je opozoriti na skladenjske in pomenske različnosti, kot se kažejo v stalnih besednih zvezah (idiomatskih in neidiomatskih), v vezljivostnih vzorcih in tudi širše v podrednih skladenjskih zvezah v obeh obravnavanih jezikih. Avtor kot frazeološke enote pojmuje (a) prehodne glagolske zveze, in sicer zgolj tiste, katerih sklonska realizacija desnega določila je v obeh jezikih različna; (b) zveze pridevnika in desnega določila $z$ izkazano različno sklonsko realizacijo; (c) samostalniške besede/zveze, in sicer glede na nasprotje beseda (zloženka) - besedna zveza in glede na drugačno razvrstitev prilastkov (levi-desni) ob samostalniški odnosnici v obeh jezikih. Merilo izbora omenjenih zvez je izključno skladenjsko; pomenske lastnosti so upoštevane samo z vidika pomenske prekrivnosti v obeh jezikih, ne pa tudi v smislu frazemskega pomena, tj. spremembe pomena sestavin frazema glede na pomen zveze kot celote. Zveze, ki ustrezajo omenjenemu merilu, so v skladu $\mathrm{z}$ »različnostno« zasnovo sprejete samo, če se izhodiščni (slovarski) pomen sestavine frazema v obeh obravnavanih jezikih ne pokriva, npr. sln. zelena-madž. rumena zavist; $\sin$. zdrava-madž. trezna pamet. 
Med »pravo« frazeološko gradivo je mogoče šteti pregovore, vendar tudi tu v mejah različne sestavinske zapolnitve. Avtor med pregovorne šteje tudi stavčnočlenske frazeme kot delati iz muhe slona; kaj ni ne tič ne miš, čeprav skladenjsko sorodne, npr. počutiti se v devetih nebesih; metati kaj $v$ isti koš; pije kot žolna ipd. imenuje reke in rekla. Samostojna skupina frazeoloških enot so mu tudi "pogosti jezikovni klišeji iz vsakdanjega življenja«. Ker pa posamezni tipi frazeoloških enot v slovarju niso označeni, je domala nemogoče razlikovati denimo med jezikovnimi klišeji in besednimi zvezami tipa: za kakšno boleznijo je umrl?; oni dan ga je srečal; odkleniti psa; imeti ovijalko v sobi; točiti med; zalivati cvetice; imel je čistokrvnega psa ipd.

Dvom v uporabnost slovarskega gradiva poleg odsotnosti kakršnihkoli pojasnil o virih in načinu zbiranja zbujajo tudi nedoslednosti, ki so posledica bodisi individualne bodisi ožje pokrajinske ali narečne rabe, npr. še sam ni vedel, v kaj se je zavozlal (SSKJ: zaplesti se v kaj); spraviti spanec iz koga, bodisi neizdelane slovarske zasnove. Tu so neustrezne zlasti slovarske oblike, npr. ustrezno biti fer do koga; imeti jeklene živce; pljuniti v roke; lahka ženska, vendar neustrezno: ni vreden počenega groša; adamovo jabolko se mu je videlo; v službi se je visoko povzpel; plesati do belega dne ipd. Pri nekaterih (izhodiščnih madžarskih) frazemih odsotnost pojasnila, ali gre za prosti prevod ali za dejansko tudi v slovenskem jeziku živ frazem, onemogoča izločitev frazemov oz. njihovih (morda pokrajinskih ali narečnih) variant, npr. osel v levji koži ${ }^{25}$ goska $v$ bolnici (steklenica za seč); neumen je tisti ptič; ${ }^{26}$ vsak človek enkrat znori ${ }^{27}$ ti je mačka kvas pojedla? (kaj se cmeriš?); tudi iz vodne pipe že to teče; narediti železo iz lesa ipd.

3.3 Nemško-slovenski frazeološki slovar Elizabete M. Jenko (1994) je še eden v skupini slovarjev, ki je nastal $\mathrm{z}$ namenom (ne brez naključja na dvojezičnem jezikovnem področju) zapolniti vrzel v slovenski frazeologiji. Slovar se od obeh obravnavanih dvojezičnih $\mathrm{s}$ tujim geselskim izhodiščem razlikuje v slovarsko obdelanem frazeološkem gradivu, ki sledi v uvodu predstavljeni slovarski zasnovi, ki ji je dodana primerjalna frazeološka študija.

Avtorica je izbrala najpogostejše nemške frazeme na podlagi Herzogovega nemškega frazeološkega priročnika za tujce (1974) in jih dopolnila z obsežnim Friedrichovim enojezičnim nemškim frazeološkim slovarjem (1976). Merilo pogostnosti ni posebej pojasnjeno, kot tudi ne, kako so označeni frazemi, ki niso enako pogosti v izhodiščnem in ciljnem jeziku, npr. čas presti za Däumchen drehen. Sicer pa se zdi, da je, kadar je navedenih več ustreznikov, na prvem mestu najpogostejši: ločiti zrno od plevela ${ }^{28}$ ločiti ljulko od pšenice; vrniti milo za drago; vrniti šilo za ognjilo, oziroma knjižni pred pogovornim in nižjepogovornim: imeti denarja kot

${ }^{25}$ Omenja ga Keber (1996: 281, op. 19) v družbi z nemškim ein Esel im Löwenhaut, angleškim an ass in a lions skin s pomenom 'neumnež, ki si hoče nadeti pomemben videz; strahopetec, ki hoče vzbuditi strah'.

${ }^{26}$ Bojc (19802: 160) Neumen je tisti tič, ki se sramuje svojega gnezda.

${ }^{27}$ Bojc (19802: 66) Slednjega človeka jeza obnori.

${ }^{28}$ SSKJ: ločiti zrno od plev. Podrobneje o tem Kržišnik Kolšek (1989/90: 138) in Kržišnik (1996: 136/137). 
toče/pečkaldreka; biti počasne pameti; biti trd. Sicer se zdi sprejeto frazeološko gradivo, zanašajoč se na lastno poznavanje, dovolj aktualno tudi s slovenskega vidika. Sprejeti so denimo tudi frazemi kot ne imeti zicledra (označen z ljudsko); iti okrog rit' v varžat, ki ju SSKJ ne prinaša, domnevam pa, da sta prepoznavna širšemu krogu slovenskih govorcev. Med manj pogostimi je mogoče omeniti iti po riti $k$ maši; spustiti kozla $v$ zelnik oz. je sprejet manj prepoznaven frazem, npr. za ein doppeltes Spiel spielen - igrati na dve karti (neizkazana sedeti na dveh stolih; imeti dve železi v ognju).

Pri iskanju čim večje frazeološke ustreznosti avtorica omenja informacije rojenih govorcev, vendar na različne stopnje frazeološke prekrivnosti posebej ne opozarja. Tako ni mogoče ločiti prevodov od frazemskih ustreznikov, npr. za nem. sich ins eigene Fleisch schneiden navaja sam sebi zasekati sekiro v koleno (neizkazan npr. pljuvati v lastno skledo).

Predstavljenemu slovenskemu frazeološkemu gradivu je mogoče očitati sledeče.

(a) Neustreznost slovarske oblike, npr. za nem. das liegt mir auf der Zunge sln. na jeziku imam 'poznam stvar, vem zanjo, vendar se je trenutno ne morem spomniti'. SSKJ, po katerem je povzeta razlaga, izkazuje kar nekaj sestavinsko podobnih frazemov, npr. ekspr. na jeziku imam, pa ne morem povedati; ekspr. na koncu jezika imam, pa ne morem povedati; to imam že dolgo na jeziku; molčal je, čeprav je imel besedo že na jeziku. Njihova pomenska diferenciacija je odvisna od stalne v nasprotju z zgolj s slovničnimi kategorijami omejene zapolnitve vezljivostnih mest. Ustrezna slovarska oblika z glagolom v nedoločniku in besedilno zapolnljivim desnim vezljivostnim mestom, npr. imeti to/kaj na jeziku/na koncu jezika, je toliko bolj pomembna, ker omogoča razlikovanje strukturno podobnih, vendar pomensko neprekrivnih frazemov, npr. imeti besedo že na jeziku 'hoteti spregovoriti, vendar ostati tiho', imeti že dušo na jeziku 'biti v zelo slabem stanju, tik pred smrtjo'; imeti srce na jeziku 'hitro zaupati svoja čustva'; imeti kaj že dolgo na jeziku 'že dolgo, zdavnaj hoteti povedati kaj'; imeti kaj neprestano na jeziku 'neprestano omenjati, izgovarjati se, sklicevati se na kaj'.

(a1) Glagolski frazemi z možnostjo realizacije glagolske sestavine v osebni glagolski obliki imajo v večini primerov glagol v nedoločniku, zato ni jasno, zakaj v nekaterih primerih vendarle ne, npr. ima več sreče kot pameti. Ponekod se zdi odsotnost nedoločnika glagolske sestavine pogojena $z$ lastnostjo živo- levega delovalnika, npr. prišlo mi je na ušesa, oz. z leksikalizacijo osebkovega mesta v sestavinski zgradbi frazema, npr. voda mu teče v grlo (voda teče v grlo komu); sline se mi cedijo (sline se cedijo komu).

(a2) Pri nekaterih prislovnih frazemih slovarska oblika izkazuje (običajno) zunajfrazemsko sestavino kot stalno sestavino frazema, npr. iti po liniji najmanjšega odpora. Problem označevanja relativno spremenljive glagolske sestavine ob prislovnih frazemih je evidenten $\mathrm{v}$ večini frazeoloških slovarjev. Rešitev $\mathrm{z}$ navedbo glagola kot nadomestka za glagole sorodnega pomenskega polja, $\mathrm{v}$ danem primeru (narediti kaj) po liniji ... se mi zdi v takih primerih najustreznejša slovarska rešitev.

(a3) Ponekod slovarska oblika skladenjsko ne ustreza zahtevam slovenskega jezika, npr. za nem. j-m in die Quere kommen sln. priti komu navzkriž. Po SSKJ 
je mogoče nastaviti slovarski obliki: kaj/vse hodi/gre navzkriž/narobe (komu) in kdo/kaj si je/pride navzkriž.

(b) Neustreznost pomenske razlage je navadno povezana $\mathrm{z}$ napačno izbiro frazemskega ustreznika, npr. za nem. nach wie vor sln. slej ko prej, ki je navedenemu pomenu 'kot doslej' blizu samo v nefrazeološkem pomenu: 'izraža nepretrganost, časovno neomejenost dejanja'. Pomen 'izraža prepričanost, gotovost, da se bo dejanje zgodilo' izkazuje SSKJ kot nefrazeološki pomen, vendar za pisavo skupaj. V frazeološkem gnezdu z razlago 'nekoč gotovo' navaja SSKJ variantno obliko prej ali slej. Za pomenske nedoslednosti gre tudi v primerih: nem. blau machen, sln. ponedeljkovati; delati plavega 'brez resnega vzroka ne iti na delo' (po SSKJ: 'neupravičeno izostati z dela'); nem. alle Brücke hinter sich abbrechen, sln. podreti vse mostove za seboj 'pretrgati vse vezi z dotedanjim življenjem' (SSKJ: 'onemogočiti si zbližanje, vrnitev').

(c) Navajanje nefrazemskega (enobesednega) ustreznika namesto frazemskega, npr. za nem. zugrunde gehen 'propasti//propadati' (po SSKJ: navzdol gre s $\mathrm{kom} / \mathrm{s} \mathrm{čim);} \mathrm{nem.} \mathrm{mit} \mathrm{der} \mathrm{Zeit} \mathrm{gehen} \mathrm{'prilagoditi//prilagajati} \mathrm{se} \mathrm{razmeram,} \mathrm{biti} \mathrm{na-}$ preden' (po SSKJ: iti/hoditi (v korak) s časom); nem. Schritt für Schritt 'postopoma ' (SSKJ: korak za korakom); nem. den Mund voll nehmen 'ustiti se' (po SSKJ: polna usta česa so koga; imeti polna usta česa); nem. glatt über die Bühne gehen 'gladko potekati' (po SSKJ: kaj/vse gre/poteka (gladko) kakor namazano/po maslu/ redko loju/redko olju/nižje pog. žnori.).

4 Frazeološko gradivo v dosedanjih slovarjih slovenskega jezika, vključno z dvo- in večjezičnimi frazeološkimi, je za izdelavo sodobnega frazeološkega slovarja lahko le dopolnilni primerjalni vir, ki slovaropisca opozori na možnost obstoja časovno pogojenega pomenskega premika, večpomenskost in na variante, med katerimi je treba $\mathrm{z}$ vidika sodobnega uporabnika izločiti zlasti zastarele in narečne. Ker večina slovarjev frazeološkega gradiva ne obdeluje sistematično, zlasti v smislu ustreznih slovarskih oblik, ki bi ločevale frazemsko besedilno okolje od njegove tipične realizacije na eni strani in frazemskega jedra na drugi, so slovarski postopki z današnjega vidika manj uporabni. Znotraj tega tudi SSKJ, sicer še vedno najobsežnejša zbirka deloma slovarsko obdelane frazeologije, ne more biti temeljno gradivo za izdajo sodobnega frazeološkega slovarja slovenščine. Tako se zdi, da je frazeološko gradivo v starejših slovarskih priročnikih in zbirkah kot edini dokumentirani vir slovenske zgodovinske frazeologije primerno predvsem za diahrone frazeološke raziskave. Bistvenega pomena pri tem je poleg izpisa frazeološkega gradiva $\mathrm{z}$ vsemi podatki, ki jih predvideva slovar, upoštevanje okoliščin nastanka slovarja, pojasnitev slovarske zasnove in namena, $v$ gradivnem smislu pa izpostavitev deleža živega (govorjenega) jezika, upoštevanje tujejezičnih predlog, predvsem pa preverjanje rabe $\mathrm{v}$ besedilih posameznih obdobij.

Zdi se, da se ob vprašanju uporabnosti frazeološkega gradiva tako v smislu aktualnosti kot ustreznega slovarskega opisa vrtimo v začaranem krogu: frazeografske slabosti obravnavanih slovarjev izhajajo predvsem iz dejstva, da Slovenci nimamo splošnega razlagalnega enojezičnega frazeološkega slovarja. 


\section{Navedenke}

BREZNIK, Anton, 1926, Slovenski slovarji, Razprave Znanstvenega društva za humanistične vede III, Ljubljana, 110-114, 116-126, 143, 247, 249.

- - 1938, Iz zgodovine novejših slovenskih slovarjev, Časopis za zgodovino in narodopisje 33, 17-32, 87-98, 147-165.

GANTAR, Polona, 2001, Teoretični vidiki zasnove frazeološkega slovarja slovenščine, Magistrska naloga.

HAJNŠEK-HOLZ Milena, 1997, Pleteršnikov Slovensko-nemški slovar kot vir za Slovar slovenskega knjižnega jezika, Jezikoslovni zapiski 3, Ljubljana, Inštitut za slovenski jeziki Frana Ramovša ZRC SAZU, 105-112.

HUMAR, Marjeta, 1998: Frazeologija kot ponazarjalno gradivo v Pleteršnikovem Slovensko-nemškem slovarju, Pleteršnikov Slovensko-nemški slovar, Zbornik s simpozija '96 v Pišecah, ur. Jože Toporišič. 87-96.

KEBER, Janez, 1996, Živali v prispodobah 1, Celje, Mohorjeva družba.

- 2000: Raziskovanje slovenske frazeologije - sedanje stanje in zasnova frazeološkega slovarja, Jezikoslovni zapiski 6, Ljubljana, Inštitut za slovenski jezik Frana Ramovša ZRC SAZU, 81-116.

- - 2001, Razlaganje izvora slovenskih frazemov, Skripta 5, zbornik za učitelje slovenščine kot drugega/tujega jezika, Ljubljana, str. 35-50.

KRŽIŠNIK KOLŠEK, Erika, 1988, Frazeologija v moderni, Magistrska naloga.

- - 1989/90, Frazeologija v osnovni in srednji šoli, Jezik in slovstvo 35, 134-141.

- - 1991, Frazeologija v slovenskem časopisju 1991, 27. seminar slovenskega jezika, literature in kulture, Zbornik predavanj, Ljubljana, Filozofska fakulteta, 89-98.

KRŽIŠNIK, Erika, 1995/96, Mali frazeološki rječnici in Hrvatsko-slovenski frazeološki rječnik, Jezik in slovstvo 41/3, 157-166.

- - 1996, Norma v frazeologiji in odstopi od nje v besedilih, Slavistična revija 44/ 2, 133-154.

-- 1998: Socialna zvrstnost in frazeologija. 34. Seminar slovenskega jezika, literature in kulture. Zbornik predavanj. Ljubljana: Filozofska fakulteta. 53-69.

--1999, Frazeologija v Murkovem slovarju, Murkov zbornik, ur. Marko Jesenšek, Maribor. 312-347.

--2001, Vsebina (slovenskega) frazeološkega slovarja za tujce - določitev in preizkus meril, Skripta 5, zbornik za učitelje slovenščine kot drugega/tujega jezi$k a$, Ljubljana , 7-32.

LEVSTIK, Fran, 1882, Zbirka slovenskih pregovorov iz leta 1592, Ljubljanski zvon II/1882, Ljubljana, 562-564, 640.

MATEŠIĆ, Josip, PETERMANN, Jürgen, 1991, Über die Redensarten in Franc Metelkos »Lehregebäude der slovenischen Sprache«. Obdobja 11, 151-159.

PETERMANN, Jürgen, 1988, Frazeologija v Slovarju slovenskega knjižnega jezika (I-IV); Nekaj osnovnih vprašanj o vlogi frazeologije v slovarju, Obdobja $8,301-310$.

PRUNČ, Erik, 1979, Prispevek k poznavanju virov za Gutsmannov slovar. (Gutsmannova jezikovnoinovacijska dejavnost) Obdobja 1, 209-265. 
RADICS, Peter, 1882, Zbirka slovenskih pregovorov iz leta 1592, Kres II/1882. Celovec. 332-334.

STABEJ, Jože, 1966, Nekaj ugotovitev ob popolnem izpisu Vodnikovega rokopisnega nemško-slovenskega slovarja, Jezik in slovstvol/2, 42-44.

- - 1977, Hieronimus Megiser, Thesaurus Polyglottus, Slovensko besedje z latinskimi in nemškimi pomeni za Slovensko-latinsko-nemški slovar izpisal in uredil Jože Stabej, Razred za filološke in literarne vede, Dela 32, Ljubljana, SAZU.

- - 1997, O Kastelec-Vorenčevem slovarju, Slovensko-latinski slovar, Po Matija Kastelec - Gregor Vorenc, Dictionarivm latino-carniolicvm (1680-1710), Ljubljana, ZRC SAZU, 563-575.

SUHADOLNIK, Stanislav, 1960/61, Josip Pavlica: Frazeološki slovar v petih jezikih, Jezik in slovstvo 6/6, 200-205.

- - 1984, Glonarjev slovar slovenskega jezika, Obdobja 5, 505-517.

TOPORIŠIČ, Jože, 1973/74, K izrazju in tipologiji slovenske frazeologije, Jezik in slovstvo 8, 273-279.

VIDOVIČ MUHA, Ada, 1996, Razvojne prvine normativnosti slovenskega knjižnega jezika, Jezik in čas, Ur. A. Vidovič Muha, Ljubljana, Znanstveni inštitut Filozofske fakultete, 15-40.

- - 1999, Čas in prostor, ujeta v slovenski slovar 20. stoletja (Poudarek na komunikacijskem vidiku Slovarja slovenskega knjižnega jezika), 35. seminar slovenskega jezika, literature in kulture, Zbornik predavanj, Ljubljana, Filozofska fakulteta, 7-26.

\section{Slovarji in zbirke}

BOJC, Etbin, $1980^{2}$, Pregovori in reki na Slovenskem, Ljubljana.

CIGALE, Matej, 1860, Deutsch-slovenisches Wörterbuch, A-L; M-Z, Laibach.

FABJAN BAJC, Diomira, 1995, Slovensko-italijanski frazeološki slovar, Dve muhi na en mah / due piccioni con una fava, Gorica, Mohorjeva družba.

FRIEDRICH, Wolf, 1976, Moderne deutsche Idiomatik, München.

GLONAR, Joža, 1936, Slovar slovenskega jezika, Ljubljana.

GRAFENAUER, Ivan, 1935, Gutsmannov besednjak in njegova zbirka pregovorov, rekov in prilik, Časopis za zgodovino in narodopisje 30, 1-29.

GUTSMANN, Ožbolt, 1789, Deutsch-windisches Wörterbuch mit einer Sammlung der verdeutschen windischen Stammwörter, und einiger vorzüglichern abstammenden Wörter, Celovec.

HERZOG, Annelies, MICHEL, Arthur, RIEDEL, Herbert, 1974, Deutsche idiomatische Redewendungen für Ausländer, Leipzig.

JARNIK, Urban, 1814, Sbér lépih ukov sa Slovensko mladino: is Némshkiga ino Latinskiga prestavlenih, is Staro-Slavenskiga ino Pemskiga preravnanih, nikotérih pa novo sloshenih, Celovec.

JENKO, M., Elizabeta, 1994, Sich auf die Socken machen / vzeti pot pod noge. 
KARNIČAR, Ludwig, 1990, Der Obir-Dialekt in Kärnten, Wien 1990.

\section{Slovenian Phraseology in Existing Dictionaries with Regard to Modern Lexicographic Principles}

\section{Summary}

Phraseology is a rather specific part of the lexical and linguistic systems and this is reflected in the Slovenian lexicographic practice from the very beginning - the phraseology is subordinate to other lexis and is unequally presented. The first lexicographic attempts started with foreign-language main entries. Later on, the Slovenian phraseological corpus had been subordinated to foreign notional concepts (Menac, Rojs; Jenko). Even when the main entry was in Slovenian (Mukič; Fabjan Bajc) it was accepted only because of the existence of its foreign equivalent. None of this groups provides relevant phraseological corpus material for modern use. Pleteršnik's Slovenian-German Dictionary (Slovensko-nemški slovar, 1894) can be regarded as a step forward, because it introduced genuine Slovenian phraseology and drew from actual usage. Similarly, Murko's Slovenian-German Dictionary (Slovensko-nemški slovar, 1833) is valuable for its account on phraseology in written sources and in literature of that time. These two dictionaries serve as the main source for diachronic phraseological studies, especially in research of time-related semantic shifts, variants and stylistic evaluation. In relation to the Dictionary of Standard Slovenian (Slovar slovenskega knjižnega jezika, 1970-1991) Pavlica's Phraseological Dictionary of Five Languages (Frazeološki slovar v petih jezikih, 
1960) is a useful source of phrasemic variants and possibilities for potential semantic differentiation. Although the Dictionary of Standard Slovenian still remains the largest collection of phraseological units with at least partial lexicographical treatment, its phraseology reflects mainly literature and, to a limited extent, journalistic texts from the $19^{\text {th }}$ and the first half of the $20^{\text {th }}$ century. However, this collection contains neither a sufficient amount of currently used phraseological units nor enough information on their syntactic role, transformational possibilities and their leftward or rightward valency. The semantic explanations need corrections in the presentation of the current semantic shifts, as well as in the supplementation of contextual explanations and information on lexicalized extralinguistic circumstances of usage. Lexicographic treatment, especially in bilingual phraseological dictionaries, does not meet the requirements of a full dictionary description: the deficiencies concerning the correct usage and understanding of a phraseme mostly appear when: the form of the main entry is incomplete or inappropriate, the context is quoted as lexicalized component of the phraseme, e.g. *afera je dvignila veliko prahu 'the affair caused a lot of excitement'** (correct: kaj dvigne veliko prahu 'something causes a lot of excitement'), the valency is presented inconsistently in the dictionary form, e.g. * pasti mrena $\mathrm{z}$ oči 'to begin to see clearly' (correct: mrena pade z oči komu 'somebody begins to see clearly'), the less appropriate Slovenian phrasemes or descriptions are given instead of an idiomatic rendering, e.g. for German sich ins eigene Fleisch schneiden, Slovenian sam sebi zasekati sekiro v koleno 'to cut one's own knee with an axe' (not shown: pljuvati v lastno skledo 'to harm oneself'). 